Удк: 612.313.3:616.8-008.615.1:612662(.9]-7

\title{
HOW TO ANALYZE TEST OF SALIVA MICROCRYSTALISATION AS A PREDICTOR OF STRESS RESISTIBILITY AND AN APPROXIMATE OVULATION TIME?
}

\author{
Andriana Belyak, Oksana Zayachkivska \\ Danylo Halytsky Lviv National Medical Univercity, Lviv, Ukraine, \\ beliachka7@gmail.com
}

\begin{abstract}
:
Aim: The aim of the study was to reveal the relationship between stress resistibility levels and saliva microcrystallization and to investigate whether menstruation phase has influence on the saliva microcrystalisation.
\end{abstract}

Methods: The group of obseravtion included 26 healthly women aged 19-30. Facies of saliva were investigated by microscopic analysis of hydration of drops of mixed saliva (Havriluk, 2014). For estimation of stress resistibility levels questionnaire created by ISMA (International stress management association, 2011) was used. To reveal the influence of menstrual phase on the microcrystalisation saliva facies were collected from women every three days during the menstrual cycle.

Results: It was discovered that the absence of microcrystalisation (4th type) was most often seen among people with low stress resistibility. What about relationship between saliva microcrystalisation and menstrual cycle there was the trend of high incidence of 1st and 2nd types during the ovulation.

Conclusions: Saliva investigation of microcrystallization types can be used as an additional method of estimation of stress and as a method of the approximate detection of the ovulation, so it can be used for planning pregnancy. Method of evaluation of saliva microcrystallization types is a helpful tool for detection of characteristic of hormonal cycle and can be used for patients with secondary amenorrhea, surgical menopause and prescription of hormonal replacement treatment or specific treatment (e.g. chemotherapy).

Kye words: biofluids, saliva, non-invasive samples, crystalisation, stress resistibility, ovulation time

\section{ЯК ІНТЕРПРЕТУВАТИ МІКРОКРИСТАЛІЗАЦІЮ СЛИНИ ЯК ПРЕДИКТОРА ОПІРНОСТІ ДО СТРЕСУ ТА ПРИБЛИЗНОГО ЧАСУ ОВУЛЯЦІї?}

\author{
Андріана Беляк, Оксана Заячківська \\ Львівський національний медичний університет імені Данила Галицького, \\ beliachka7@gmail.com
}

\begin{abstract}
Актуальність: у цілому світі делалі більшу увагу привертає до себе лабораторне дослідження слини. Перевагами $\epsilon$ неінвазивність і економічніть, що може спонукати використовувати дослідження слини набагато ширше і легше, аніж аналіз крові. Дане дослідження стосувалося мікрокристалізації слини, тобто її здатності утворювати кристали. Загально відомим $€$ зв'я-
\end{abstract}


зок між мікрокристалізацією слини та патологією травної системи, захворюваннями ротової порожнини, стоматологічними захворюваннями.

Мета: проаналізувати, чи $є$ взаємозв'язок між рівнем опірності до стресу та мікрокристалізацією. А також з'ясувати, чи $є$ залежність між фазою менструального циклу у жінок та особливостями мікрокристалізації слини.

Методи і матеріали: групу спостереження склали 26 здорових жінок, віком від 19 до 30 років. Фації слини досліджувались методом дегідратації краплі змішаної слини (Гаврилюк, 2014). Для визначення рівня опірності до стресу використовувалися опитувальники, створені міжнародною організацією по боротьбі зі стресом (ISMA, 2011).

Для виявлення впливу фази менструального циклу на мікрокристалізацію, фації слини збиралися у жінок кожні 3 дні впродовж місяця.

Результати: було виявлено, що відсутність мікрокристалізації (4 тип) найчастіше зустрічалася серед людей із низькою опірністю до стресу. А щодо взаємозв'язку між мікрокристалізацією та менструальним циклом, то під час овуляції спостерігалася висока частота 1-ого і 2-ого типів кристалізації.

Висновки: дослідження слини може бути використане, як додатковий метод оцінки рівня стресу і для приблизної оцінки часу овуляції. Також оцінка мікрокристалізації може бути застосована для планування вагітності і призначення специфічного лікування.

Ключові слова: біологічні рідини, слина, неінвазивні зразки, кристалізація, стрес опірність, овуляція

\section{Background:}

40 years ago among scientists awarded the Nobel Prize in Physiology or Medicine 1977 on «for their discoveries concerning the peptide hormone production of the brain» was Roger Guillmin (H. Selye's PhD student in 1949-1953) who discovered of Corticotropin Releasing Factor, CRF, as key master hormone of stress reaction, and whole hypothalamic-pituitaryadrenal axis was identified. Based on this and plenty other additional observations, the basic and clinical research on stress is extensive and multidisciplinary in all areas of medicine, however, the tools of identification stress manifestation in humans is still limited $[1,2]$. Moreover, WHO developing the International Classification of Diseases, version 11 (ICD-11) is included stress-spectrum diseases in it. Acute and chronic changes and adaptation during stressful life events may trigger accelerated aging, as well as psychological disorders and oncogenesis $[3,4,5,6]$. Determining personal stress level in real time could be of special interest in health monitoring, wellbeing and early prediction of stress-associated disorders. Recent data suggests that biofluids are very promised for health monitoring and creation non-invasive diagnostic tool for personal control and prevention decline of natural stress-resistibility. Recent data has shown that saliva secretome study is growing body of evidences for its using, as easy and early diagnostic tool $[7,8,9,10,11]$.

Crystallization of saliva is the process of formation of solid crystals precipitating from a solution in which a solute from a liquid solution to a pure solid crystalline phase occurs. Crystallization is therefore an aspect of precipitation, obtained through a variation of the solubility conditions of the solute in the solvent, as compared to precipitation resulting from chemical reaction $[12,13,14]$.

The crystallization process consists of two major events: nucleation and crystal growth. Nucleation is the step in which the solute molecules dispersed in the solvent (water) start to gather into clusters. However, if the clusters are not stable, they redissolve. The crystal growth is the subsequent growth of the nuclei that succeed in achieving the critical cluster size. Once the first small crystal - the nucleus - forms, it acts as a convergence point for molecules of the solute touching or adjacent to the crystal so it increases its own dimension in successive layers. Nucleation and growth continue to occur simultaneously as long as supersaturation exists. Su- 
persaturation refers to a solution that contains more of the dissolved material than could be dissolved by the solvent and thus, the rate of nucleation and growth is driven by the existing supersaturation of the solution. The level of supersaturation can be increased by, among other methods, allowing the solution to evaporate. Depending on the conditions, either nucleation or growth may be predominant and as a result, crystals with different sizes and shapes are obtained. The nature of the crystallization process is governed by both thermodynamic and kinetic factors (motion of the molecules and the forces and energy acting on them), which can make it highly variable and difficult to control [15, $16,17]$.

It is usually much easier to dissolve a perfect crystal in a solvent than to grow a good crystal again from the resulting solution, which means that the nucleation and growth of a crystal are primarily under kinetic, rather than thermodynamic control (18). Thus, we hypothesized that study of biophysical and functional properties of saliva microcrystallines regarding to the hormonal control would be helpful methods of personalized control of health and wellbeing.

Aim: The aim of the study was to reveal the relationship between stress resistibility levels and saliva microcrystallization and to investigate whether menstruation phase has influence on the saliva microcrystalisation.

Methods: The group of obseravtion included healthy 26 women aged 19-30.

Facies of saliva were investigated by dehydration of drops of mixed saliva $(19,20)$ and 4 types saliva of microcrystallization were indentified microscopic analysis (Fig. 1). For estimation of stress resistibility levels questionnaire created by ISMA (International stress management association, 2011) was used.

To reveal the influence of menstrual phase on the microcrystalisation saliva facies were collected from women every three days during the menstrual cycle 3d, 6th, 9th, 13th, 18th days (Fig. 2).
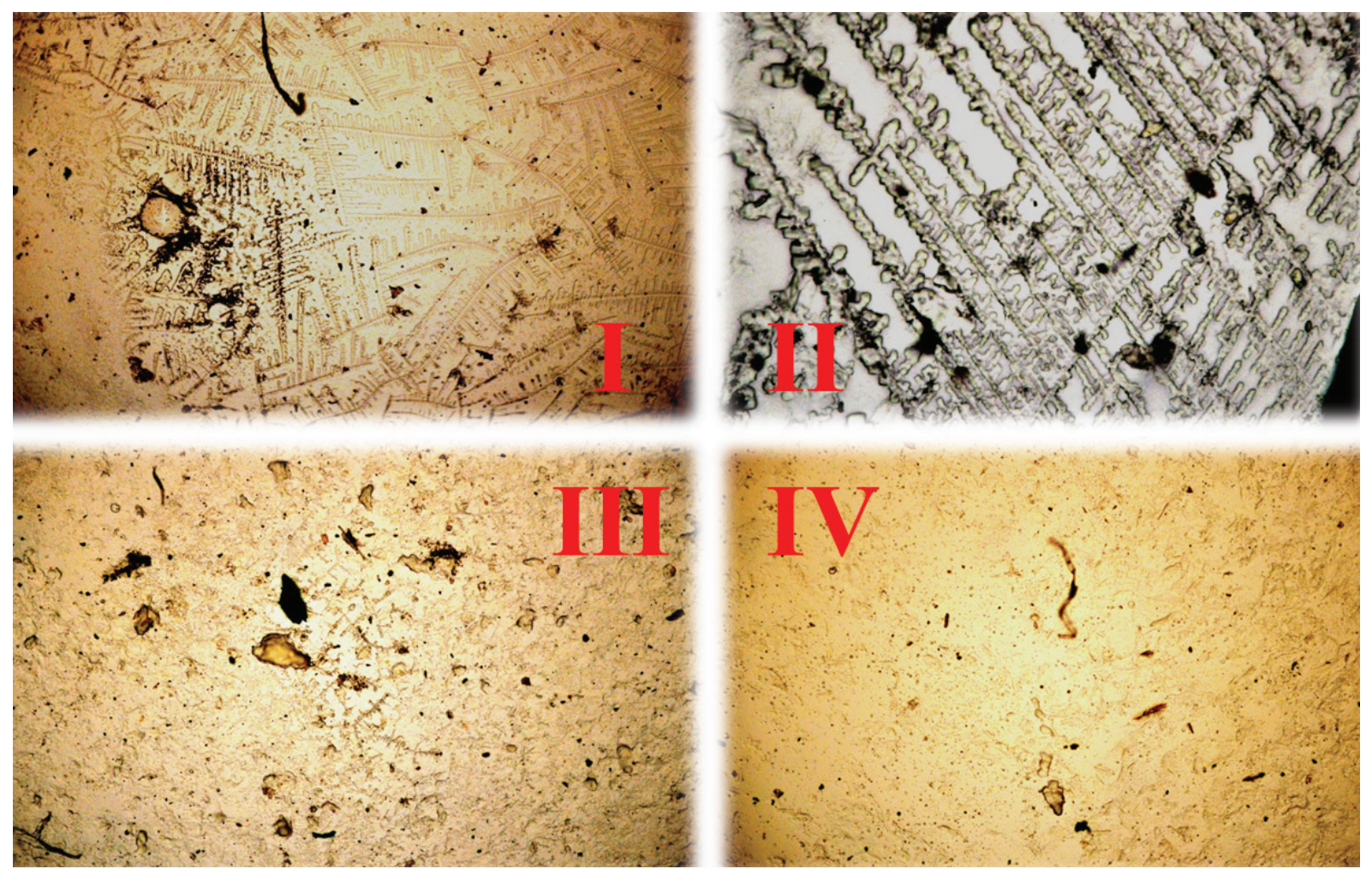

Figure 1 . Types of saliva microcrystallization 


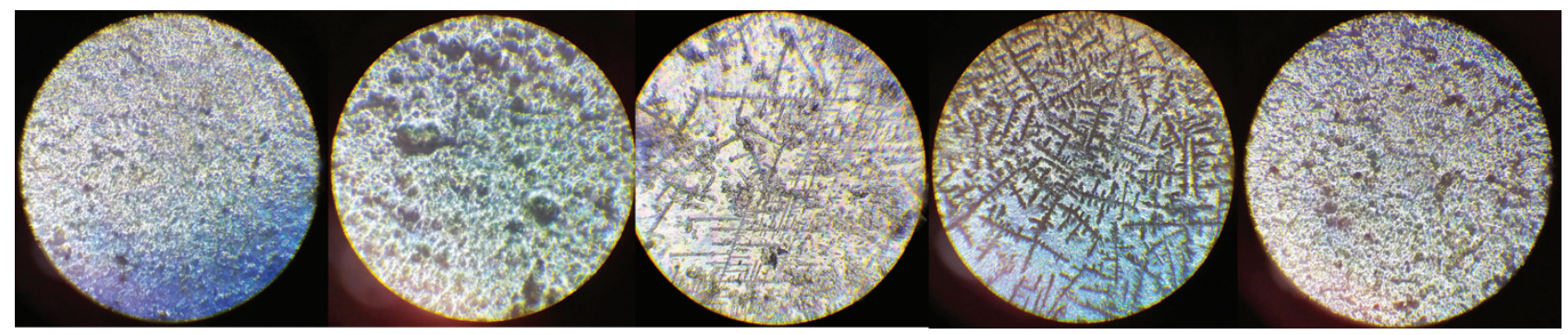

Figure 2. Case study of crystallization during menstrual cycle. Visualisation by smartphone.

Results: It was discovered that the absence of microcrystalisation (4th type) was most often seen among people with low stress resistibility $(44,4 \%)$, while there were $35,3 \%$ of 4 th type among people with medium resistibility and no this type among people with high resistibility (Fig. 3).

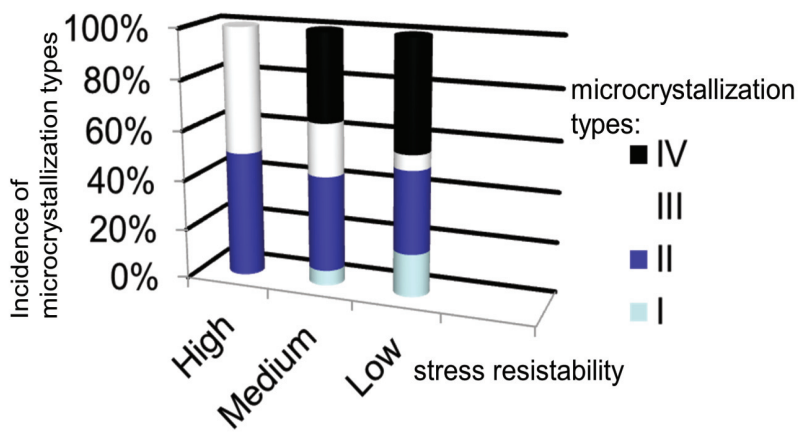

Figure 3. Distribution of microcrystallization types depending on stress resistibility levels.

What about relationship between saliva microcrystalisation and menstrual cycle, all types of crystalisation were seen with the equal incidence with the trend of high incidence of 1st and 2nd types during the ovulation (Fig. 4).

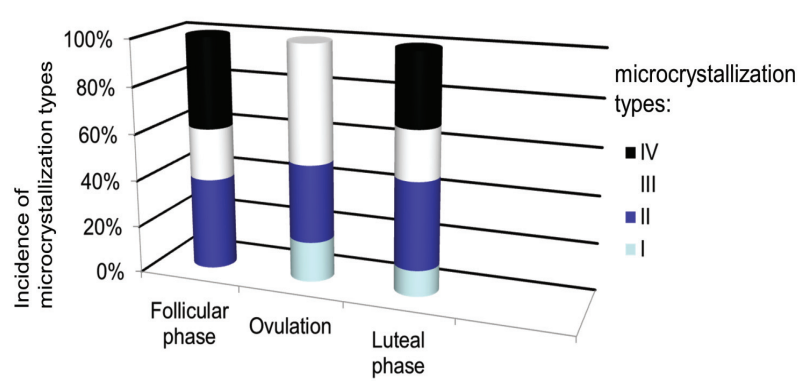

Figure 4. Distribution of microcrystallization types depending on menstrual cycle phases.

\section{Conclusions:}

Saliva investigation of microcrystallization types can be used as an additional method of estimation of stress and as a method of the approximate detection of the ovulation, so it can be used for planning pregnancy.

Method of evaluation of saliva microcrystallization types is a helpful tool for detection of characteristic of hormonal cycle and can be used for patients with secondary amenorrhea, surgical menopause and prescription of hormonal replacement treatment or specific treatment ( e.g. chemotherapy). This method is very simple, cheap and noinvasive, so it can be used widely.

\section{References}

1. Maercker A, Brewin CR, Bryant RA, Cloitre $M$, Reed GM, van Ommeren M, Humayun A, Jones LM, Kagee A, Llosa AE, Rousseau C. Proposals for mental disorders specifically associated with stress in the International Classification of Diseases-11. The Lancet. 2013 May 11;381(9878):1683-5.

2. Cozma S, Dima-Cozma LC, Ghiciuc CM, Pasquali V, Saponaro A, Patacchioli FR. Salivary cortisol and a-amylase: subclinical indicators of stress as cardiometabolic risk. Brazilian Journal of Medical and Biological Research. 2017;50(2).

3. Petrakova $L$, Doering $B K$, Vits $S$, et al. Psychosocial stress increases salivary alpha-amylase activity independently from plasma noradrenaline levels. Schmidt U, ed. PLoS ONE. 2015;10(8):e0134561. doi: $10.1371 /$ journal.pone.0134561.

4. Vineetha R, Pai K-M, Vengal M, Gopalakrishna K, Narayanakurup D. Usefulness of salivary alpha amylase as a biomarker of chronic stress and stress related oral mucosal changes - a pilot study. J Clin Exp Dent 2014;6(2):e132-e137. doi:10.4317/jced.51355. 
5. Lakhtin Y., Moskalenko P., Levkov A., \& Smeyanov Y. Application of saliva crystalloscopy methods in the diagnosis of malignant tumours of salivary glands and Sjögren disease (Doctoral dissertation, Published by IASHE London), 2015.

6. Wiley JW, Higgins GA, Athey BD. Stress and glucocorticoid receptor transcriptional programming in time and space: Implications for the brain-gut axis. Neurogastroenterol Mot. 2016;28(1):12-25.

7. Zayachkivska O.S. The role of salivary endogenic bioregulators in the formation esophagoprotection at experimental injury of the esophagus. Contemporary Gastroenterology 2006;30 (4):65-71. (In Ukrainian).

8. Bazin D, Letavernier E, Haymann JP. Biomineralization versus microcrystalline pathologies: Beauty and the beast. Comptes Rendus Chimie. 2016;19(11):1395-403.

9. Mori M., Ishikawara F., Tomoda T., Yamada S., Okamoto M., Itabashi H., Sumino H. Use of capillary electrophoresis with dual-opposite end injection for simultaneous analysis of small ions in saliva samples from wrestlers undergoing a weight training program. J Chromatogr B Analyt Technol Biomed Life Sci. 2016;1012:178-185.

10. Choi M. Saliva diagnostics integrate dentistry into general and preventive health care. Int J Prosthodont. $2010 ; 23(3): 189$

11. Wong D.T. Salivary diagnostics powered by nanotechnologies, proteomics and genomics. J Am Dent Assoc. 2006;137(3):313

12. Tominaga, K., Fujikawa, Y., Tsumoto, C., Kadouchi, K., Tanaka, F., Kamata, N., Arakawa, T. Disorder of autonomic nervous system and its vulnerability to external stimulation in functional dyspepsia. J Clin Biochem Nutr. 2016;58(2):161-5. doi: 10.3164/jcbn.15-140.

13. Bonaz B. Stress and the Gastrointestinal System. In Neuro-Immuno- Gastroenterology 2016 (pp. $123-$ 156). Springer International Publishing.

14. Brzozowski B, Mazur-Bialy A, Pajdo R, Kwiecien S, Bilski J, Zwolinska-Wcislo M, Mach T, Brzozowski T. Mechanisms by which Stress Affects the Experimental and Clinical Inflammatory Bowel Disease (IBD): Role of Brain-Gut Axis. Curr Neuropharmacol 2016;14(8):892-900. Stevens RG, Zhu Y. Electric light, particularly at night, disrupts human circadian rhythmicity: is that a problem? Phil Trans R Soc B 2015 May 5;370(1667):20140120.

15. Proper K. I., Singh A. S., Van Mechelen W., Chinapaw M. J. Sedentary behaviors and health outcomes among adults: a systematic review of prospective studies. Am J Prev Med. 2011;40(2): 174-182.

16. Thorp A. A., Owen N., Neuhaus M., Dunstan D. W. Sedentary behaviors and subsequent health outcomes in adults: a systematic review of longitudinal studies, 1996-2011. Am J Prev Med.. 2011;41(2):207215.

17. Haruma K., Kinoshita Y., Sakamoto S., Sanada K., Hiroi S., Miwa H. Lifestyle factors and efficacy of lifestyle interventions in gastroesophageal reflux disease patients with functional dyspepsia: primary care perspectives from the LEGEND study. Internal Medicine. 2015;54(7):695-701.

18. Kroll JL, Werchan CA, Reeves AG, Bruemmer KJ, Lippert AR, Ritz T. Sensitivity of salivary hydrogen sulfide to psychological stress and its association with exhaled nitric oxide and affect. Physiology \& Behavior. 2017 Oct 1;179:99-104.

19. Wiegand C, Savelsbergh A, Heusser P. MicroRNAs in Psychological Stress Reactions and Their Use as Stress-Associated Biomarkers, Especially in Human Saliva. Biomedicine Hub. 2017;2(3).

20. Havryliuk N.S., Kindrat A.B., Cymbalista I.V. Clinical value of crystallization of saliva in patients with acid-dependent diseases. Contemporary gastroenterology. 2014 №6(80) [In Ukrainian] 